\title{
ADMINISTRATION OF A MUSLIM'S ESTATE UNDER SECTION 17 OF THE PUBLIC TRUST CORPORATION ACT 1995 WITH SPECIAL REFERENCE TO TRANSFER OF VEHICLES
}

\author{
Muhammad Amrullah bin Drs Nasrul * \\ Wan Noraini Mohd Salim**
}

\begin{abstract}
As one of the administrative bodies, Amanah Raya Berhad (ARB) possesses jurisdiction in administering the deceased's movable estate through the issuance of letters of declaration and direction respectively. Applying for such document requires the applicant to attach the fara'id certificate as part of the application. The problem, however, is the superfluity of the fara'id certificate in estate cases involving the transfer of ownership of the deceased's vehicle. This is due to the rule set by the Road Transport Department (RTD) which allows for only a single name to be registered as the new owner, and thus renders the fara'id certificate inoperable. Since the ARB still requires the fara'id certificate in cases involving the administration of vehicles, this requirement is burdensome to the beneficiaries as they have to incur additional costs, as well as spend time and effort to obtain the certificate. This article addresses the problem in relation to estate administration by ARB involving vehicles under Section 17 of the Public Trust Corporation Act 1995 and analyses the implication of such rule towards estate administration. It is based primarily on the analysis of written sources, namely, textbooks, statutes, by laws and journals. The findings from this article show that there is a need to improve the policy of the ARB and the RTD in providing a more efficient means to the public in the administration of the estate of a Muslims.
\end{abstract}

Researcher, Islamic Law Department, Ahmad Ibrahim Kulliyyah of Laws, International Islamic University, Malaysia, P.O. Box 10, 52780 Kuala Lumpur. E-mail: amrullah.edu@gmail.com.

** Assistant Professor, Islamic Law Department, Ahmad Ibrahim Kulliyyah of Laws, International Islamic University, Malaysia, P.O. Box 10, 52780 Kuala Lumpur. E-mail: w.noraini@iium.edu.my. 
Keywords: fara'id certificate, estate, administration, vehicle, registration

\title{
PENTADBIRAN HARTA PUSAKA ORANG ISLAM DI BAWAH SEKSYEN 17 AKTA PERBADANAN AMANAH RAYA 1995: RUJUKAN KHAS TERHADAP PINDAHMILIK KENDERAAN
}

\begin{abstract}
ABSTRAK
Sebagai salah sebuah badan pentadbir, Amanah Raya Berhad (ARB) mempunyai bidangkuasa dalam mentadbir harta alih pusaka simati melalui pengeluaran surat Akuan dan Arahan. Sebelum mendapatkan dokumen tersebut, sijil fara'id diperlukan sebagai sebahagian dari permohonan. Masalah yang wujud adalah berkenaan dengan sijil fara'id yang tidak digunapakai dalam kes pengurusan harta pusaka melibatkan kenderaan simati. Ini disebabkan oleh peraturan yang ditetapkan oleh Jabatan Pengangkutan Jalan (JPJ) dimana hanya satu nama yang dapat didaftarkan sebagai pemilik baru dan ini menyebabkan sijil fara'id tidak dapat diaplikasikan. Disebabkan ARB memerlukan sijil fara'id untuk permohonan kes pentadbiran kenderaan simati, syarat ini dilihat membebankan waris-waris dari segi kos, masa dan komitmen dalam mendapatkan sijil tersebut. Artikel ini menyenaraikan masalah berkaitan pentadbiran harta pusaka dibawah Seksyen 17 Akta Perbadanan Amanah Raya 1995 dan menganalisa kesan peraturan tersebut terhadap pentadbiran kenderaan simati. Artikel ini berpandukan kepada analisis dari sumber-sumber bertulis termasuk buku teks, statut, undang-undang kecil dan jurnal. Dapatan dari artikel ini menunjukkan wujudnya keperluan dalam menambah baik polisi ARB dan JPJ dalam menyediakan kaedah yang lebih efisien kepada masyarakat.
\end{abstract}

Kata kunci: sijil fara'id, pentadbiran harta pusaka, kenderaan, pendaftaran 


\section{INTRODUCTION}

Estate administration is a process that deals with the assets of the deceased, comprising a series of tasks, including a collection of the assets, payment of debts as well as the distribution of assets. According to Curzon, estate administration also involves the appointment of a personal representative, a person who is authorised to manage the deceased's estate. ${ }^{1}$ Under the Malaysian inheritance law, the personal representative in testate cases is known as the executor where his appointment is made through the will. ${ }^{2}$ In intestate cases, the administrator is appointed through the letter of administration issued by the administrative bodies. ${ }^{3}$. Despite the different terms, their tasks are more or less similar as they are authorised to administer the deceased's estate.

Among the essential aspects which need to be considered in the administration of the estate is the duration of the administration. The duration in administering the deceased's estate is subject to several aspects. One of them is the types of the deceased's asset. ${ }^{4}$ In normal circumstances, the movable asset is easier and speedier to be administered compared to the immovable asset. This is due to its asset realisation procedures which do not involve various and complicated tasks. Realisation of assets covers the process of gathering the deceased's assets which includes collection from every institution which holds the deceased's assets such as banks, insurance, companies and another third party. Each and every asset, belonging to the deceased, needs to be gathered and this includes the deceased's vehicle. Under the Malaysian inheritance context, the vehicle is a movable asset which is also subjected to distribution under estate

Appointment of personal representative is subjected to testate and intestate cases. Executor is appointed in testacy while the administrator is appointed in intestacy. In addition, appointment of administrative under Form F of the Estate Distribution Unit also occurs under the issuance of letter of administration by the land administrator.

Section 3 of Probate Administration Act 1959 (Act 97).

Curzon L.B. Dictionary of Law ( $6^{\text {th }}$ edition) International Law Book Services.

See Rozita Ramli and Nur Jannah Mohd Taib. "Analisis Berstatistik Untuk Tempoh Tuntutan Harta Pusaka: Satu Kajian Kes Di Melaka." 1 LNS(A) Ixix, $C L J$ (2012). The authors list down three criteria which determine the jurisdiction of the administrative bodies namely testacy or intestacy cases, the value of the asset and the type of asset. 
administration. ${ }^{5}$ Though it is part of the deceased's asset, the administration and disposition of the deceased's vehicle are slightly different as compared to others.

While other movable assets such as cash and jewellery, can be distributed to the beneficiaries according to the prescribed or agreed portions, distribution of the deceased's vehicle cannot be made based on such similar method. In practice, there are two methods on how the deceased's vehicle can be administered. The first one is by liquidating the asset, where the proceeds from the sale can be distributed to the beneficiaries based on fara'id. The second one is by registering the name of one of the beneficiaries as the new owner of the vehicle. In this case, the registered beneficiary is considered as buying the shares of others in exchange of becoming the owner the car. However, the rule prescribes that only one person can be registered as the new owner. Therefore, the beneficiaries have to decide in whose name the vehicle should be registered ${ }^{6}$.

In practice, the process of transferring the ownership of the vehicle from the deceased to the beneficiary requires letters of declaration or direction from the ARB. The Corporation ${ }^{7}$ possesses the jurisdiction to deal with a movable estate where the value is RM600,000 and below. However, in cases involving a deceased Muslim, the application for the declaration and direction from ARB requires the applicant to attach the fara' $i d$ certificate which must be issued by the Syariah Court. ${ }^{8}$

Nonetheless, the Road Transport Department (RTD) ${ }^{9}$ does not require the fara' id certificate in the registration of a vehicle. Thus, the

See Abdul Hakim Mohammed, Abdul Hamid Mar Iman \& Adibah, "Pembangunan Harta Tanah dan Pelestarian Alam," Paper presented at the Seminar Pembangunan Harta Tanah Kebangsaan Menurut Perspektif Islam. Institut Kefahaman Islam Malaysia, Kuala Lumpur, Malaysia, August 2009.

6 As required in the JPJ K3A Form which stated the requirement to furnish the court order or letters of representation from any administrative bodies, including the ARB.

7 Amanah Raya Berhad (ARB) is defined as the "Corporation" under the Public Trust Corporation Act 1995. See the interpretation under Section 2 of the said Act.

8 Wan Abdul Halim Wan Harun, "Isu-isu Pembahagian Harta Pusaka Orang Islam dalam Konteks Perundangan Malaysia," Jurnal Pengurusan JAWHAR 3 (2009): 159-187; Pusaka (n.d), accessed 25 January 2017, http://www.arb.com.my.

9 The Road Transport Department of Malaysia, hereinafter known as the RTD is one of the government agencies under the Land Division, Ministry of Transport Malaysia. One of the main function of the RTD is to provide services for 
prerequisite set by the ARB for the beneficiaries to obtain the fara' $i d$ certificate before the issuance of any declaration or direction is burdensome since they have to incur additional time and expenses in obtaining the certificate. This is especially true in cases where the value of the vehicle is not that high which makes the requirement to obtain the certificate seems disproportionate to the commitment and the cost of making the application for the fara'id certificate. Ultimately, the vehicle needs to be transferred to the new owner for the purpose of insurance and road tax renewal. The implication of failure to transfer the ownership of the vehicle is stated in the later part of the article.

This article addresses the implications resulting from the difference in the requirements set by the ARB and RTD in the administration of a vehicle belonging to a deceased Muslim. At the same time, the article will propose solutions to simplify the process of transferring the ownership of the vehicle to the beneficiaries. It is also aimed at reducing the burden and hardship of the beneficiaries from going through the tedious process..

\section{THE IMPORTANCE OF THE FARA'ID CERTIFICATE}

In Malaysia, the law does not require the fara'id certificate to be obtained prior to the application for the administration and distribution of a deceased Muslim's estate. However, in practice, certain administrative bodies such the High Court and the Estate Distribution Unit require the fara'id certificate to be enclosed with the application for estate distribution. ${ }^{10}$ The reason behind such requirement is that any decision as to the distribution of the deceased asset shall be made by the court judge or the land administrator in accordance with the fara'id certificate. ${ }^{11}$ The importance of the

licensing and registration of vehicles. In relation to the estate administration, the transfer of the ownership involving the deceased's vehicle is under the jurisdiction of the RTD.

10 See Fazira Shafie, Wan Yusoff, Wan Zahari, Syed Abdullah, \& Syed Muhammad Dawilah al-Edrus, "Islamic Real Estate Management: Review on Issues and Challenges in Managing Inheritance Property in Malaysia," Paper presented at the $25^{\text {th }}$ International Business Information Management Association Conference, 2015.

11 In normal cases, the fara'id certificate is not required for the application under the Estate Distribution Unit since the land administrator possess the expertise in 
fara'id certificate is to identify the deceased's heirs as well as to ascertain their portion from the deceased's estate based on the law of fara'id. Hence, details regarding the list of the deceased heirs and their portion are stated in the certificate. ${ }^{12}$

Jurisdiction to issue the fara' $i d$ certificate is given to the Syariah court. ${ }^{13}$ Technically, application for the fara'id certificate is made to the Syariah Lower Court or Syariah High Court, depending on the value of the estate. The law regarding the fara'id certificate is governed by the state's Syariah Enactment, and it varies from one state to another. ${ }^{14}$ In practice, the process of applying for the fara'id certificate is not a straightforward process. There are several stages, including the application process, verification of facts by the court and the issuance of the fara'id certificate. The application from the applicant must be enclosed with the required documents such as the heirs' Identification Cards, deceased's death certificate, marriage certificate and others. Normally, the fara'id certificate will be issued within a few days after the application except in certain circumstances. $^{15}$ During the hearing session, the judge will inquire concerning the heirs of the deceased's estate and entitled heirs as part of the brief investigation session. After affirming the portion of the beneficiaries and other related issues during the said session, the court

fara'id calculation. However, if the complex or difficult situation involves, the land administrator will require the beneficiaries to obtain the fara'id certificate from the syariah court.

12 See Noraini Noordin, Adibah Shuib, Mohammad Said Zainol, and Mohamed Azam Mohamed Adil, "Delay in Islamic Inheritance Claim-An Ignorance Issue," Procedia-Social and Behavioral Sciences 90 (2013): 504-512.

13 See Suhaimi Mahbar, "Transformasi Pengurusan Pentadbiran Harta Pusaka di Malaysia: Cabaran dan Penyelesaiannya," Paper presented at the Seminar Kebangsaan Transformasi Pengurusan Harta Pusaka, Malaysia, September, 2016.

14 For instance, under Section 65 of the Administration of the Religion of Islam (State of Selangor), Enactment 2003 empowers the Syariah court to issue the fara'id certificate. Aspects such as the process, requirements and duration for the issuance of fara'id certificate differs for the Syariah court in each states as matters relating to religion falls under the state jurisdiction, as construed in the Federal Constitution 1957.

15 Application for fara'id certificate may take a considerable time to settle if there are important issues such as identifying and determining the status of the heirs. In practice, the court will inquire, request the family members to testify or to produce the evidence pertaining to the issues which the court deemed necessary. This justifies the need for each family members, particularly the deceased's heir to appear at the Syariah court during hearing. 
will then issue the fara'id certificate to the applicant. The fara'id certificate will be enclosed with other required documents for the purpose of applying for the letters of representation from any administrative body.

In an application for Declaration and Direction under section 17 of the Public Trust Corporation Act 1995, ARB requires the fara'id certificate to be attached with the application. Based on the fara'id certificate, the ARB would be able to identify the beneficiaries as well their entitled portion. However, the corporation will conduct their investigation to confirm the validity of the information given by the applicant regarding the entitled beneficiaries and their portion. ${ }^{16}$ This is because there are cases where the applicant hides certain beneficiaries and do not include their name in the fara'id certificate. The list of beneficiaries and their portion in the fara'id certificate which is issued by the Syariah court is made based on the information given by the applicant. Should the applicant conceal the existence of even one beneficiary, such action will jeopardise the right of the beneficiary and his entitlement in the deceased' estate.

\section{JURISDICTION}

Amanah Raya Berhad (the Corporation) is one of the administrative bodies which deal with the deceased's estate administration besides the civil High Court and the Estate Distribution Unit. ${ }^{17}$ The Corporation is statutorily empowered under the Public Trust Corporation Act 1995 (PTCA) to issue certain documents which authorise the corporation to administer the estate for the applicant. The jurisdiction of ARB covers the value of movable assets below RM600,000 in both testate and intestate cases. ${ }^{18}$ These types of

16 The ARB officers who are directly deal with cases involving the estate administration of the deceased are given training and courses in fara'id calculation, hence able to calculate the fara'id portion of the beneficiaries.

17 Estate Distribution Unit is formerly known as the Small Estates Distribution Section. Estate Distribution Unit possesses the jurisdiction in estate administration involving small estates, where the value involved is two million ringgit and below, comprising of immovable asset or a combination of immovable and movable asset.

18 See Fatin Afiqah Md Azmi, Muhammad Tahir, \& Syed Mohammad, "The Causes of Unclaimed, Late Claimed or Distributed Estates of Deceased Muslims in Malaysia," Proceedings of International Conference on Sociality and 
estates fall under the category of the summary estate. There are two types of documents issued by ARB, namely Declaration and Direction. The declaration is specified under Section 17(1) of Public Trust Corporation Act 1995 which states: ${ }^{19}$

1) Whenever any person dies, whether testate or intestate leaving movable property in Malaysia and the Corporation is satisfied after such investigation as it deems sufficient

(a) that the total value of the property without deduction for debts, but not including the value of any property which the deceased possessed or was entitled to as trustee and not beneficially, does not exceed six hundred thousand Ringgit; and

(b) that no person is entitled to apply to the Court for grant of probate of will or no petition for letters of administration is pending,

the Corporation shall, upon the application of a person making a claim on the property and if it thinks fit to do so, by writing declare that it undertakes to administer the property, and thereupon the Corporation shall be empowered to administer the property.

Under this section, the Corporation is authorised to issue a Declaration upon application from the beneficiary. This section also implies the exclusive jurisdiction of the ARB which cannot be interfered by other administrative bodies. There is a difference between Declaration, letters of representation issued by the High Court and Letters of Administration issued by the Estate Distribution Unit. ${ }^{20}$ The Declaration empowers the ARB not only to issue a letter of representation but also allows the corporation to administer the deceased's estate. The term "administer" includes a collection of tasks including execution and distribution of the estate. This denotes the role of ARB as the personal representative of the estate of the deceased. As a comparison, letters of representation by the High Court or Estate Distribution Unit only formalise the appointment of a personal representative. The role of these institutions is discharged upon the issuance of such letters. However, the Declaration in this

Economics Development (ICSED), Kuala Lumpur, Malaysia, 10 (2011): 440444.

19 Public Trust Corporation Act 1995 (Act 532).

20 The term letters of representation refers to both Grant of Probate and Letter of Administration being issued by the civil High Court. On the other hand, Letter of Administration is also issued by the Estate Administration Unit under the abbreviation of Form F. 
context serves as a self-appointment for the ARB as the personal representative where it is duty-bound to administer the estate of the deceased until its completion. The role of the ARB is not discharged upon the issuance of the Declaration.

Direction, on the other hand, covers the movable estate in which the value is RM50,000 and below. Section 17(2) (a) of the Act states that:

\begin{abstract}
When the Corporation is satisfied that the value of any property referred to in subsection (1) does not exceed fifty thousand ringgit, it may direct that the same or any part thereof be delivered to any person or persons on being satisfied as to the title of the claimant and value of the property by the oath or affirmation of the claimant or by such other evidence as the Corporation may require and the Corporation may in its discretion take such security as it thinks proper for the due administration of the property or the protection of the rights of any other person.
\end{abstract}

Based on the above provision, Direction and Declaration differ not only in terms of the value but also in terms of the effect on the deceased's estate administration. In practice, the Direction allows the beneficiaries to collect the deceased's asset from the related institutions themselves. This is similar to the Distribution issued by the Estate Distribution Unit which enables the beneficiary to procure the deceased's estate. In other words, the collection and distribution of the deceased's assets will be handled by beneficiaries themselves. The involvement of ARB ceases upon the issuance of Direction.

\title{
ADMINISTRATION AND DISTRIBUTION OF VEHICLES
}

Administration and distribution pertaining to vehicles are not the same as other types of assets. Although it employs a method similar to the transfer of lands and shares which involves registration of a beneficiary as the new owner, the transfer of a vehicle only allows for one name to be registered in the vehicle registration, which is reflected through the vehicle registration document. ${ }^{21}$ Through the

21 Unlike houses or lands which allow for multiple names to be registered as the owner, only one name can be registered as the owner of a vehicle. Therefore, if the deceased died leaving a car for example, the ownership can be transferred to 
transfer process, the ownership of the vehicle shifts from the deceased to the named beneficiary as the new owner of the vehicle. However, this can be done only if there is no outstanding or unpaid car loan balance. Otherwise, the registration cannot take effect unless the loan is settled. The payment can be settled via car insurance or through direct payment from the beneficiary.

Since the car can only be registered under one name, other beneficiaries cannot obtain ownership of the car. Should other beneficiaries insist on their rights over the car, the only method to obtain the share from the vehicle is by selling it as part of liquidating the asset. The proceeds of the sale will then be distributed to the beneficiaries in accordance to their portion under fara'id. There are two sale methods which are normally practised. The first is to sell the vehicle to a third party, and the proceeds will be divided accordingly. The second practice is to sell the vehicle to the heir whose name is registered as the new owner. He will either use his money to pay for the vehicle price or in cases where there are other types of estate, the new car owner will surrender his portion according to fara'id based on his share value in exchange for obtaining the said vehicle. This, however, can only be done by the mutual consent of all beneficiaries.

\section{VEHICLE TRANSFER PROCEDURES}

Since the vehicle of the deceased is part of his estate, such vehicle cannot be sold to another person before the transfer of ownership to a single beneficiary is effected. Even though all the beneficiaries agree for the car to be sold, such transaction cannot be done prior to the transfer of ownership from the deceased to the beneficiary. Such transfer process must comply with the rules set by the Road Transport Department (RTD). There several documents which need to be provided by the applicant for the transfer process. The primary document is the letters of a representation obtained either from the High Court, Estate Distribution Unit or the ARB. Others include the deceased and recipient's Identification Card, the vehicle registration card as well as the form provided by the RTD known as the JPJK3A

only one person. The registration process is made via the use of the instrument known as the JPJK3A form. 
form. ${ }^{22}$ The transfer process will take place upon completion of all documents, together with the payment of a certain amount as the transfer processing fee. Nonetheless, the fara'id certificate is not among the required documents in cases involving a deceased Muslim, since the law requires only a single name to be registered as the new owner. Once the transfer process takes place, the name of the new owner will be made available on the vehicle registration card, signifying him as the new owner. From this point, the new owner can dispose the vehicle through sale or transfer the vehicle to a third party, according to his wishes. Unfortunately, some of the new owners tend to ignore the right of the other beneficiaries of the sale money after selling the car. This is perhaps due to the perception of the new owner that the vehicle belongs to him as he has become the sole owner after the transfer has taken place. ${ }^{23}$

The rule set by the RTD states that the transfer process must be applied for personally by the recipient. This is because the process will require the recipient's fingerprint verification in the database system. In cases involving administration by the ARB, the corporation will prepare the necessary documentation and hand it over to the recipient for the actual transfer process which needs to be done at the RTD office.

\section{IMPLICATIONS}

The determination of administration of a deceased's vehicle under Section 17(1) or Section 17(2) is dependent on its value. ${ }^{24}$ In cases

22 JPJK3A Form is an instrument which is used to transfer the ownership of vehicle from the deceased to the beneficiary. It is stated in the form that the transfer of ownership can be made to a single name only. This rule goes in line with the concept of ownership of vehicle which is stated in the vehicle registration certificate.

23 According to the feedback given the ARB officer, this situation usually happens in two situations. The first situation involves a beneficiary who are older and disregard the portion of others younger than him. The second involves a beneficiary is appointed as the personal representative to administer the asset but failed distribute the portion of the asset to others. Based on the interview conducted by the writer during his attachment program in January until March 2016.

24 The ARB administers the movable asset where the value is RM600, 000 and below. If the value of the subject matter exceeds the stated amount, the asset will fall under the jurisdiction of the civil High Court. 
involving a deceased Muslim, ARB will require the applicant to obtain the fara'id certificate even in cases involving the administration of a single vehicle. There are many cases involving the administration of the deceased's vehicle only. Despite the fact that the deceased passed away leaving a single car, such vehicle is still considered his estate, and therefore, must be administered in a manner similar to other types of estate.

In practice, the transfer process at the RTD does not require procurement of the fara'id certificate since only one name can be mentioned in the transfer. This renders the application of fara' $i d$ insignificant since the fara'id distribution method cannot be applied in this matter. ${ }^{25}$ Therefore, a requirement by the ARB as to the fara 'id certificate is considered unnecessary and burdensome to the beneficiaries, but still, it remains as a requirement by the ARB as they cannot proceed with the administration without such document.

The ARB requirement for the fara'id certificate forces the beneficiaries to spend additional time and incur expenses in obtaining the certificate, which is not part of the required documents for the purpose of vehicle ownership transfer in the RTD. The process of obtaining the fara'id certificate requires the attendance of all beneficiaries, and this may be very difficult to achieve without the commitment of all beneficiaries. A specific time convenient for all beneficiaries has to be fixed to attend the hearing session. This discourages the beneficiaries from initiating the estate administration process, especially in cases involving a vehicle of low value. Moreover, some people are sceptical about dealing with the court. It is believed that they feel intimidated, insecure and unconfident to deal with the syariah or civil judiciary, thinking that they might be prone to punishment for any wrongdoing from the court. The wrong perception about the Syariah court too has sometimes led to the delay in commencing the estate administration process. According to Wan Noraini, social attitude is one of the causes for the delay in the administration of estates. ${ }^{26}$ In other words, it is the ignorance of the

25 Fara'id calculation is vital in any case involving the estate of the Muslim. However, the fact that fara'id certificate is not required during the vehicle transfer process as law the law only allows for one person to be registered led to the issue of the significance of the fara' $i d$ certificate in the first place.

26 Wan Noraini Mohd Salim, Problems in the Administration and Distribution of Intestate Estate in Malaysia with Special Reference to its Foundation in Customary Law, Islamic Law and English Law, PhD Thesis, University of Exeter, United Kingdom, 2002. 
beneficiaries as to their rights and obligations in estate administration that contributed to the incidence of estates left un-administered in Malaysia. ${ }^{27}$ Consequently, no effort is made to transfer the ownership of the vehicle and the deceased remains as the owner of the vehicle.

Such reluctance in initiating the estate administration could bring adverse implications to the beneficiaries. First of all, the vehicle cannot be transferred or sold to a third party due to the vehicle status which is still under the ownership of the deceased. No valid transaction of the vehicle can take place, so long as the administration is not commenced. Stalling the administration will also decrease the value of the vehicle due to the depreciation factor. ${ }^{28}$ This will lead to economic loss, especially if the beneficiaries wish to sell the vehicle. Another implication is that renewal of the vehicle road tax and insurance cannot be done after a certain amount of time. According to the policy set by the RTD, the beneficiaries can renew the deceased's road tax twice a year, up to three years from the date of the last renewal. Administration of the vehicle should, therefore, be made before the expiration of the said period.

Without renewing the insurance of the vehicle, the driver is exposed to grave danger since the vehicle is not indemnified. The driver will not be able to claim insurance if the vehicle is involved in an accident. Evidently, driving the car without a valid road tax is an offence and can be penalised by the authority. In general, failure to commence the administration of the estate of the deceased, even if it only involves a single vehicle, will only add to the list of estates left unadministered in Malaysia which has reached up to sixty billion Ringgit. ${ }^{29}$

\section{SUGGESTIONS}

The above issue has caused difficulty to the public as they need to obtain the fara'id certificate prior to applying for the letter of

27 Abdul Rusnadewi Rashid, Siti Asishah Hassan, \& Noor Inayah Yaakub, “A Need for Legal Framework of Gift Inter Vivos (Hibah) in Malaysian Estate Planning," Paper presented at the Kuala Lumpur International Business, Economics and Law Conference, 2013.

28 Unlike lands and houses whose value increase, vehicle suffers from depreciating factors which reduce its value for each year.

29 Fazira Shafie, et al, "Islamic Real Estate Management." 
declaration or direction from the ARB. Due to this, some of them felt discouraged to commence the administration. Prompt action must be taken in order to improve the process in obtaining the Direction or Declaration from the ARB. Based on the analysis conducted on the application process by both the ARB and RTD, there are several improvements which could be proposed to improve the process of obtaining the letters.

Firstly, it is proposed that the ARB needs to review the requirement for estate administration, omitting the fara'id certificate as a required document. It is understood that even though the fara 'id certificate is not applicable to the vehicle transfer process, the said document is important to determine the existing heirs, as well as their prescribed portion, should the vehicle eventually be sold. Without prejudice and without intention to undermine the importance of the fara' id certificate, the writer believes that the Corporation has similar capability in determining the entitled heirs as well as their entitled fara'id portion. ARB has the expertise to do the fara' id calculation since their role as personal representative requires them to be familiar with the formula when dealing with the estate of the deceased Muslim.

In addition, the ARB possesses a link with the National Registration Department which allows them to conduct a search for the status of a person through a specific database. ${ }^{30}$ With sufficient capability owned by the corporation, the requirement for the fara'id certificate may be waived. In exchange, the corporation itself could determine the rightful heirs and their prescribed portion under fara ' $i d$. The corporation circulation and policy must be amended so that appointment for estate administration under Section 17 can be made without requiring for fara'id certificate from the applicant in certain special circumstances. The focus here is to minimise the hardship on the part of the beneficiaries from having to deal with several institutions. The suggestion is to authorise the corporation to issue an order similar to the fara'id certificate ${ }^{31}$ which is exclusive for the application of Letters of Declaration and Direction under Section 17.

30 Through the database system known as Agency Link-Up System (ALIS), the ARB can search the information of the beneficiary, particularly in investigating and searching for the missing heir. Accessed January 10, 2016 , http://www.arb.com.my.

31 The term "order" refers to the Fara'id Distribution Order or in this context, known as the fara'id certificate. 
Such order can either be produced through a production of a document consisting of fara'id information or by integrating the fara'id information into the Declaration and Direction Order respectively. The officer who endorses such fara'id information should be an officer who is competent and possesses expertise in fara'id. As such, such officers must be properly certified, similar to the concept of the ARB officers who are gazetted under the government gazette which enables them to represent the Corporation in discharging their duties formally.

Secondly, the same fara'id certificate can be issued by the Syariah court officer through collaboration between the Syariah court and the ARB. For example, the ARB can provide a venue for the Syariah court judges to have a hearing session, specifically for cases under section 17 of Public Trust Corporation Act 1995. A concept similar to circuit courts can be adopted, which would enable the issuance of fara'id certificates in a speedier manner. Despite maintaining the requirement of a fara'id certificate, this proposal could help to reduce the burden of the beneficiaries of having to deal with multiple institutions in different locations.

\section{CONCLUSION}

The difficulty in the administration of the deceased's estate varies, ranging from a simple to a difficult case. Administration of vehicles do not involve a complicated procedure, compared to other types of estates such as immovable assets. With sufficient documentation, the vehicle can be transferred to the named beneficiary within a short time. However, the requirement set by ARB in demanding the fara ' $i d$ certificate seems to impose an unnecessary burden on the beneficiaries, since the major purpose of the certificate in this case is the confirmation of the entitled beneficiaries. The ARB itself could undertake such confirmation, in addition to the calculation of fara'id. The fact that the fara'id certificate is not required for the transfer process under the RTD is not in consonant with the requirement set by the ARB. Such apparent inconsistency between the two institutions should be remedied immediately.

The proposed ideas focus on the centralisation of the administration under a single institution, which could speed up and improve the process for the benefit of the beneficiaries in applying for 
the administration. Administration of estates involving deceased Muslims should not be seen as complicated as opposed to the administration of non-Muslim estates. In fact, good collaboration between related institutions including the Syariah Judiciary could improve the administration of estates, and thus benefit the public. A system which is good and easy to handle could encourage the public to proceed with estate administration, reducing the number of cases of estates left un-administered. 